\title{
Protecting Buddhist Women from Muslim Men: "Love Jihad" and the Rise of Islamophobia in Myanmar
}

\author{
Iselin Frydenlund
}

check for updates

Citation: Frydenlund, Iselin. 2021. Protecting Buddhist Women from Muslim Men: "Love Jihad" and the Rise of Islamophobia in Myanmar. Religions 12: 1082. https://doi.org/ $10.3390 /$ rel12121082

Academic Editor: Aje Carlbom

Received: 20 September 2021 Accepted: 24 November 2021 Published: 8 December 2021

Publisher's Note: MDPI stays neutra with regard to jurisdictional claims in published maps and institutional affiliations.

Copyright: (C) 2021 by the author. Licensee MDPI, Basel, Switzerland. This article is an open access article distributed under the terms and conditions of the Creative Commons Attribution (CC BY) license (https:/ / creativecommons.org/licenses/by/ $4.0 /)$.
Department for the Study of Religion, MF Norwegian School of Theology, Religion and Society, 0363 Oslo, Norway; Iselin.Frydenlund@mf.no

\begin{abstract}
Buddhist protectionism in contemporary Myanmar revolves around fears of the decline of Buddhism and deracination of the amyo (group/"race"). Buddhist protectionists and Burmese nationalists have declared Islam and Muslims the greatest threat to race and religion, and Myanmar has witnessed widespread distribution of anti-Islamic and anti-Muslim content, as well as massive violence against Muslim minority communities, the Rohingya in particular. The Indian neologism "Love Jihad" has scarce reference in contemporary Burmese Buddhist discourses, but, importantly, the tropes of aggressive male Muslim sexuality and (forced) conversion through marriage ("love jihad") have been one of the core issues in Buddhist protectionism in Myanmar. The article shows that such tropes of the threatening foreign male have strong historical legacies in Myanmar, going back to colonial Burma when Burmese concerns over Indian male immigrant workers resulted in both anti-Indian violence and anti-miscegenation laws. Importantly, however, compared to colonial Indophobia and military era xenophobic nationalism, contemporary constructions are informed by new political realities and global forces, which have changed Buddhist protectionist imaginaries of gender and sexuality in important ways. Building on Sara R. Farris' concept of "femonationalism", and Rogers Brubaker's concept of civilizationism, the article shows how Global Islamophobia, as well as global discourses on women's rights and religious freedom, have informed Buddhist protectionism beyond ethnonationalism in the traditional sense.
\end{abstract}

Keywords: Myanmar; gender; "love jihad"; sexuality; reproduction; anti-Muslim; Islamophobia; Buddhist protectionism; Burmese nationalism; femonationalism

\section{Introduction}

In 2013, Buddhist monastic associations and networks in Myanmar began drafting laws to protect Buddhist women in mixed marriages. By 2014, the initiative had grown into four draft laws to protect "race and religion", and in 2015-after strong pressure from Buddhist monastic associations-the laws were passed in Parliament. The laws aimed to prevent the alleged "Islamization" of Buddhist majority Myanmar, by restricting Buddhist women's marriage rights, by state regulation of conversion, and by introducing "birth-spacing" policies in areas of the country where women were thought of as having too many children. While not stated in the legal text itself, it was widely believed that the birth-spacing policy was aimed at Rohingya Muslim women. The laws were passed in a context of vehement Buddhist protectionism, monastic mobilization in the public sphere, online and offline Islamophobic discourses and violence against Muslim minority communities, the Rohingya in particular. Muslim men are seen as posing the ultimate threat to the perceived purity of the Burmese Buddhist identity, and at the heart of Buddhist Islamophobia are questions about gender, sexuality and reproduction, as well as notions of Buddhist women as reproducers of the "nation". This article seeks to analyze constructions of the male Muslim "Other" as a threat to Buddhist women, using "love jihad" as an analytical category. In doing so, I will explore to what extent concepts such as "femonationalism" and "civilizationism" can work as useful theoretical frameworks 
for unpacking the multiple layers of Buddhist Islamophobia and its gendered imaginaries. This article is divided into four parts. I begin by making conceptual clarifications with regard to "Islamophobia" and "Buddhist nationalism", and furthermore, clarifying the conceptual framework of "love jihad" and "femonationalism". I then move on to discuss colonial legacies of anti-Indian and anti-Muslim sentiments, before I analyze contemporary Buddhist Islamophobia, including tropes of "love jihad" and miscegenation laws. Finally, the article discusses "love jihad" in Myanmar with reference to regional and global forces, exploring to what extent circulation of global tropes has informed local concerns, and if so, what that means for our understanding of Islamophobia and new forms of nationalism.

On 1 February 2021, the military in Myanmar staged a coup. The article contains a postscript on the coup, reflecting on how gender and notions of "racial" purity are played out in both resistance and support of the military state.

\section{Conceptual Clarifications: Buddhist Islamophobia, Buddhist Protectionism, "Love Jihad" and "Femonationalism"}

The emergence of contemporary anti-Muslim and anti-Islamic Buddhist groups such as the 969 and MaBaTha (discussed below) raise important questions about conceptualizations: are we to understand them as "Buddhist nationalism", and if so, what is the "nation" in "Buddhist nationalism"? Niklas Foxeus (2019, p. 663) suggests that Burmese Buddhist nationalism should be analytically understood as "an ideological ethnic-nationalist ressentiment discourse that also informs a religio-nationalist discipline". In sermons held by famous nationalist monks, a recurrent theme is the Buddha as a nationalist, protecting his "race" and religion. Sometimes, this theme is linked to a narrative depicting the Burmese people - the Burmese nation (referring to the 135 national "races")—as blood-descendants of the Buddha's Shakya clan. In this ideology, Foxeus suggests, Buddhism and national identity are fused. However, concepts such as "nation" and "race" are as contextual as they are disputed in Myanmar, which makes the category "Buddhist nationalism" a conundrum. Buddhism is closely linked with the majority Bamar ethnic identity, which is captured in the colonial era slogan "to be Bamar is to be Buddhist". However, many groups among the 135 officially recognized "national races"1 also identify as Buddhist. Ethnic minority groups such as the Arakanese (the majority population in the Rakhine state bordering Bangladesh, but also home of the Rohingya population), the Mon, the Shan or the majority of the Karen identify as Buddhist. Thus, the relationship between Buddhism, ethnicity and "nation" is highly complex, and one misses an important dimension of Buddhist identity formation if one overlooks Buddhist concerns which (at important points) transcend ethnic/"racial" boundaries. This does not mean that amyo is not important in contemporary discourse, but that its meaning is highly contextualized and can refer to group/ethnicity/"race" (for example Bamar or Karen), the 135 "national races" (taing-yin-tha) recognized by the state, or the Buddhist community Myanmar. ${ }^{2}$

Furthermore, the term "Buddhist nationalism" does not really capture that in Myanmar, "Buddhist nationalism" can include ethnic majority nationalism (Burmese Buddhist nationalism dominated by the Bamar ethnic group), but also ethnic minority nationalism (e.g., Rakhine or Karen Buddhist nationalism). In sermons given by MaBaTha monks, ethnic belonging is subordinated to religious belonging, and as Foxeus has shown, the "nation" in this context refers to ethnic groups of the 135 "national races" who are Buddhist (and not the others). ${ }^{3}$ This position, however, might also be understood as reflecting Bamar majority privileges (cf. Walton 2013), ignoring Buddhist ethnic minority separatist aspirations. Another way of understanding the concerns of such "Buddhist nationalist" discourse is to explore "race" and "nation" from a different angle. When Buddhist monks root their identity in racial notions of being descendants from the Buddha's Shakya clan we can speak of a racialized Buddhist identity, which strategically conflates ethnic difference, alienating other concepts of ethnicity, "race" or "nation" in Myanmar. In order to capture such trans-ethnic Buddhist concerns, and moreover, to capture the importance given to a racialized religious identity over ethnic diversity, as an alternative concept to "Buddhist 
nationalism", I will use the term "Buddhist protectionism" ${ }^{4}$, here defined as political and legal activism aimed at protecting the buddhasasana from perceived external threat, including measures to maintain ingroup purity. A core concern for Buddhist protectionism in Myanmar-as reflected in the four "race and religion" laws-is the notion that Buddhist women marry non-Buddhist men, leading to a demographic shift where the Buddhists will be a minority. This perceived need to protect women from "foreigners" has deep historical roots in Burma/Myanmar, and fears of Indian and/or Indian Muslim males have been activated and placed into central view in relation to "critical events" (Das 1995). While concerns of miscegenation between local women and "non-local" ( $k a$ bya) men seem to have been of little concern in pre-modern Burma, such fears became particularly acute in colonial Burma (Ikeya 2017, 2020; Latt 2020), and as will be analyzed in detail in this article, they were re-activated in the years of semi-civilian rule and political liberalization (2011-2021). Thus, while previous research has shown the important historical legacies of colonial era anti-Indian and anti-Muslim sentiments for our understanding of current anti-Muslim sentiments (e.g., Egreteau 2011; Kyaw 2016, 2021; Ikeya 2017, 2020), this article suggests that anti-Muslim sentiments today are also informed by contemporary concerns and global contexts, and that we need to understand how historical "reservoirs" of gendered nationalist imaginaries are reshaped and re-envisioned in new contexts. As argued below, this "reformatting" makes for a shift in our use of terminology as well, from "Indophobia" and anti-Muslim sentiments to "Buddhist Islamophobia".

"Islamophobia" is a highly controversial term, and here I rely on the definition of "Buddhist Islamophobia" as "the deep fear of a coordinated global Islamic plot to eradicate Buddhism and eventually rule the world" (Frydenlund 2018a, p. 280). This definition aims at conceptualizing a specific form of anti-Islamic and anti-Muslim concerns, excluding the damaging effects Islamophobia might have for Muslim communities in terms of exclusionary social practices and harm. While recognizing this specific weakness, the definition's strength lies in its emphasis on conspiracy theory, namely the allegation that Muslims intentionally engaged in a plot to dominate the world. This perspective is particularly important for our understanding of allegations of "love jihad", as this specific Islamophobic trope reduces love and marriage to an intentional strategy of "Islamization". Conspiracy theories are often crucial to Islamophobia and right-wing extremism in general, and academic research on conspiracy theories has much to offer for our understanding of how certain groups in society can be constructed as "enemies within", for example through so-called "subversion myths" (Robertson et al. 2018). Such ideas revolve around the notion that certain groups in society are engaged by supra-national forces to overrun current social, political and religious orders. ${ }^{5}$ In subversion myths, ethnic and religious minorities often play the role of traitors and the "enemy within", and in such myths they often are dehumanized, which in turn make them more vulnerable to violence.

Furthermore, I make an analytical distinction between anti-Muslim sentiments in colonial Burma — which was specifically linked to Indian ethnic identity—and present-day anti-Islam and anti-Muslim sentiments that compared to its historical precursors conflate Muslim identities across ethnic divisions and local belonging to a greater degree than before. The persecution of the Rohingya Muslim minority is a horrific reminder that ethnicity certainly still plays a crucial role. Nonetheless, the last decade's anti-Muslim campaigns went beyond anti-Rohingya sentiments, homogenizing all Muslim identities into one Islamic religious identity. The latter manifestation, which essentializes Islam and Muslims across time and space is arguably in itself a global phenomenon, produced in an age of "hyper-connectivity". Therefore, this definition of "Buddhist Islamophobia" is aimed at specifically capturing the weight given to Islam qua religion in contemporary Buddhist protectionist discourses, and the ways in which this is informed by global mediatization of Islam and Muslims.

At the heart of Buddhist Islamophobia, as we find it in Myanmar, Sri Lanka and Thailand, are the deep-seated fears of minoritization of the majority, or to speak with Arjun Appadurai (2006), the fear of small numbers. The fear is that Islam will eradi- 
cate Buddhism in Buddhist majority states in South and Southeast Asia, and in recent years such fears have increased dramatically in the region, largely reducing centurieslong, complex-but by and large peaceful-Buddhist-Muslim interactions to a question of Muslim imperialism and Islamization (Frydenlund and Jerryson 2020, pp. 1-21; Jerryson and Frydenlund 2020, pp. 263-97). Such fears have grown in the wake of 9/11 and the "War on Terror", the 2001 Taliban's destruction of the Buddha statues in Bamyian (which traumatized many Buddhist communities across Asia) and the rise of Global Jihadism. Additionally, the 2019 Easter attacks (the first act of political violence in the name of Islam in Sri Lanka) served as a "proof" to radical anti-Muslim Buddhist groups that Islam and Muslims pose an immediate threat to Buddhism in the island. Tropes and themes in Buddhist Islamophobia fall into six categories (adopted and revised from Frydenlund 2018a): (1) Local Muslims as non-national, expressed in a language of Buddhist "host" and Muslim "guest"; (2) Islam as security threat, followed by securitization of local Muslims such as closing of Islamic schools, "screening" of Islamic books by defence ministries or closing of mosques" ; (3) Islamic Economic Expansionism, such as notions of the "Rich Muslim" as representative of global capitalism; (4) "Demographic Jihad", with sub-themes of birth, rape and love jihad; (5) Buddhism as freedom (from Muslim oppression), based on the partial and selective use of international human rights discourses, in particular woman rights and religious freedom; and finally, (6) COVID-19 anti-Muslim racism, which became massive in Sri Lanka during the pandemic, and which resulted in compulsory cremation of dead bodies, which was particularly painful for the Muslim communities as Islam demands burials of the dead.

All of these themes have been present in Buddhist Islamophobic discourses across the region, but it is important to recognize variation and difference (see also Schonthal and Walton 2016), and that expressions of such demographic fears vary across time and space. In Buddhist Sri Lanka, for example, rumours were spread that Muslim shop-keepers put chemicals into sweets given to female Buddhist customers in order to sterilize them (Silva 2016). Also, there were widespread notions of alleged super fecundity of both Muslim males and females. ${ }^{7}$ Finally, in Sri Lanka, there has been massive concern over Muslim female dress, followed by the 2021 ban on wearing burqa and niqab. Importantly, however, concerns about conversion in mixed marriage (as expressed in the "Love Jihad" trope) are not widespread in Sri Lanka. ${ }^{8}$ By comparison, female Muslim dress has been lower on the agenda in Myanmar, and I have yet to hear conspiracy theories regarding forced sterilization campaigns against Burmese Buddhists women. Yet, as we shall see, sexuality, conversion and mixed marriage were at the core of Buddhist protectionist mobilization in Myanmar. Explaining such variance within Buddhist protectionist imaginaries across the region, needs to address how different colonial experiences and traumas in Burma and Sri Lanka (then Ceylon), have shaped current formations in particular ways.

The neologism "Love Jihad" originated in India around 2002, and among its first usages in the political sphere goes back to Hindutva organizations in South India in 2007. It was however with a court case in 2009 that the concept came into regional and national prominence (see Froystad 2021; Nielsen and Nilsen 2021). "Love Jihad" is a Hindu nationalist conspiracy theory that claims that Indian Muslims are conspiring to increase their demographic size within the Indian population by luring Hindu women into a so-called "love marriage" and eventually converting them to Islam (Gupta 2016). Within the "Love Jihad" discourse, Muslim-Hindu marriages are seen as a threat to an idealized Hindu collective moral order (Strohl 2018), as a way of "making ideal citizens-both men and women-of Hindu Rashtra" (Sarkar 2018, p. 16), as well as a a regulatory mechanism "to control the choice and mobility of young urban women" (Tyagi and Sen 2020, p. 3). As explained in the Introduction to this Special Issue (Frydenlund and Leidig Forthcoming), to what extent the neologism "Love Jihad" (is actually used by anti-Muslim Buddhist protectionists, varies. Certainly, Buddhist monks in Myanmar have used the terms "Love Jihad" and "Sexual Jihad" specifically, but still "Love Jihad" has scarce reference in Buddhist protectionist discourses in Myanmar. Importantly, however, the tropes of aggressive male 
Muslim sexuality and forced conversion through marriage are widespread and actively promoted by various Burmese Buddhist protectionist associations, including Buddhist monks. Therefore, as suggested in this article, "love jihad" (as a general noun, lowercase) is a useful analytical tool to conceptualize ideas about "Islamization" through sexuality and reproduction. Finally, taking on a comparative global perspective, the article aims to bring material from Burma/Myanmar into a wider discussion about similar ideas found elsewhere regarding the threatening "male Muslim Other", exploring similarities and differences. The article concludes that, while sharing concerns for "Islamization" through conversion in marriage with Hindutva "Love Jihad" campaigns in India, Buddhist protectionist constructions of ingroup identity and "Otherness" also share some similarities with what Sara R. Farris (2017) has coined "femonationalism". This concept is used to capture the ways in which recent manifestations of right-wing nationalism in Europe have increasingly advanced their anti-Islam agenda in the name of women's rights. "Femonationalism", a shorthand for feminist and femocratic nationalism, refers to both "the exploitation of feminist themes by nationalists and neoliberals in anti-Islam campaigns and to the participation of certain feminists and femocrats in the stigmatization of Muslim men under the banner of gender equality" (Farris 2017, p. 4). As Farris rightly points out, one of the central tropes mobilized by these right-wing nationalists is the "profound danger that Muslim males constitute for Western European societies, due, above all, to their oppressive treatment of women" (Farris 2017, p. 2). Furthermore, she argues that "one of the striking features that distinguishes contemporary European nationalist parties from their older counterparts is the invocation of gender equality (and occasionally LGBT rights) within an otherwise xenophobic rhetoric" (Farris 2017, p. 1). Farris analyzed "femonationalism" with reference to France, Italy and the Netherlands. So far, however, few studies have applied this concept to a non-Western context as an analytical tool to explore how feminist themes might be "exploited" by anti-Muslim nationalists in other cultural and political contexts. While there are obvious differences between femonationalism in Western Europe and Buddhist Islamophobia in Myanmar, this article suggests that femonationalism provides a useful conceptual framework for our understanding of Buddhist protectionist imaginaries of gender and Buddhist legal activism "to protect" Buddhist women and moreover, why they came to be widely endorsed by Buddhist women themselves. Yuval-Davis (1997) famously showed how the production of the nation involves the production of notions of manhood and womanhood which, as we shall see, fits into Buddhist protectionist discourses, but by bringing the concept of femonationalism into the analysis of anti-miscegenation laws in contemporary Myanmar, I hope to flesh out another layer in Buddhist protectionist discourse, namely one that selectively embraces global human rights. This analytical point also bears some resemblance with Rogers Brubaker's (2017) notion that there is a shift from ethnonationalism to "civilizationalism" in Europe, where Judeo-Christian civilization is conceptualized as liberal and pro-human rights, against what is constructed as a "civilization threat" from Islam. There are substantive differences between nationalist populisms in Western Europe and Buddhist Islamophobia, but concerns for women's rights and domestic violence in the context of a perceived "Islamic civilizational threat" is helpful in making us scrutinize how the construction of a "Muslim Other" influences constructions of a Buddhist protectionist identity.

\section{Colonial Legacies of Anti-Indian and Anti-Muslim Sentiments}

British colonial rule in Burma (1824-1948) led to decline in traditional socio-political orders, but at the beginning of the 20th century did also produce vibrant resistance and religious innovation, for example through new monastic and lay associations that sought to protect Buddhism from perceived decline. Religious studies scholars and historians alike have made crucial insights for our understanding of the rise of Buddhist protectionism and Burmese nationalism (Turner 2014), Buddhist innovation and modernization (Braun 2013), or re-imaginations of Buddhist political thought and practice (Schober 2011; Walton 2017). Such notions of decline are not only the result of the external threat posed by European 
colonial rule, but feed into Buddhist historiography's notions of decline of the buddhasasana, that is, "Buddhism" as a social entity in this world (Frydenlund 2018a). ${ }^{9}$ Other studies have paid attention to the importance of the colonial economy for religious and ethnic identities in colonial Burma (Campbell and Prasse-Freeman 2021; Latt 2020). As these studies rightly flesh out, British colonialism implied the implementation of a global capitalist economic system, which among other things, implied mass migration of laborers within the British colonial territories. In Burma, this meant massive labor migration of male workers from India, many of whom took on white collar jobs within the colonial hierarchy. ${ }^{10}$ Indian immigrants were feared and resented by the Burmese "because of their presence in business, administration, as well as in manual labor, and their relations with local women were perceived as an intentional Indian plot to marginalize the Burmese and exploit them" (Campbell and Prasse-Freeman 2021, p. 17). From this theoretical point of view, the production of ethnicity and xenophobia-including anti-Indian/Muslim sentiments-has to be understood in relation to racialized capitalism in the colony, and not as a priori category available for mobilization (Campbell and Prasse-Freeman 2021). ${ }^{11}$ Phyo Win Latt (2020, p. 154) makes the important observation that resentment against Indian moneylenders in Burma and the question of intermarriages intensified after the economic recession in the early 1930s. This insight on the importance of the economy for ethnic and religious identity formations is particularly relevant for our understanding of anti-miscegenation legislation in colonial Burma, but, as we shall see, also for the rise of Buddhist Islamophobia and the four "race and religion" laws in 2015.

Burma in the 1920s and 1930s witnessed the rise of strong nationalist sentiments, navigating around fears of the kala (a pejorative term in this context referring mostly to Indians) and the need to protect the amyo (group, lineage, "race", or "nation"). ${ }^{12}$ In his critical analysis of Burmese nationalist discourse in the 1930s and 40s, Phyo Win Latt (2020, p. 70) analyzes the multiple usages of the term in nationalist writings, for example amyo pyauk, which describes a "condition where a certain Amyo disappears or loses its lineage or distinct characteristics due to mixing or inter-marriage, among other things". This notion is also reflected in the Burmese saying that "A Lumyo does not face extinction by being swallowed into earth, but from being swallowed up by another Lumyo" (Latt 2020, p. 71). Burmese nationalist intellectuals and writers depicted kala as the enemy of amyo, and as Phyo Win Latt (2020, p. ix) notes, they focused "primarily on the role of Buddhist women as the subject to protect, warning them not to mingle with men from different religious and ethnic backgrounds in order to maintain the purity of Amyo". There was a massive fear that their amyo (in this context biological "race") was going to disappear, and Buddhist monks began to address the issue of amyo to female audiences, holding the view that it was a female responsibility not to marry men from different amyo and religions (Latt 2020, p. 80).

With regard to colonial intimacies, it is well known that British and European notions of racial hierarchies sought to prevent intermarriages between white women and Asian men (Stoler 2002). Importantly, however, intermarriage was not only of concern to European colonizers, but also of great concern to Asians as well. In fact, in 1930s Burma, there was strong denunciation of intimate relations between Burmese women and foreign men, in particular relations between local Buddhist women and "Indo-Burmese" and "SinoBurmese" men. ${ }^{13}$ In addition to the fears of "racial" extinction, and calls from Buddhist monks and Buddhist women together to safeguard their "race", such concerns also evolved around the legal status of Burmese Buddhist women when marrying non-Buddhist males of other "races". It is to be noted that all intermarriage (when the husband belonged to another legal tradition, be it Hindu, Muslim or Chinese Buddhist ${ }^{14}$ ) had the potential to infringe upon the rights of Burmese Buddhist women, but research on legal cases in Burmese courts shows both a great deal of resistance as well as maneuvering with regard to the management of intermarriages and mixed offspring (Ikeya 2013; Kyaw 2019). However, regardless of fluid or contradictory social realities, miscegenation, as well as mixed "race" 
became a matter of nationalist concern, perceived as a threat to the emerging independent Burma. $^{15}$

It should be noted that in the 1920s and early 30s, Muslim men seem not to be more concerning than men from other religions (Latt 2020, p. 140). This is perhaps linked to the fact that in 1931 Indian Hindu men in Burma far outnumbered Indian Muslim men (Ikeya 2013). However, a more articulated anti-Muslim discourse crystallized after the 1938 anti-Indian/anti-Muslim riots, followed by the circulation of anti-Muslim books. Two such anti-Muslim books were banned by the colonial government, namely Pathi Bathawin Myar Atwak Sinsaryan ("Things for the Muslims to Consider") and Luphauk Pathi Tharthanarpyu ("Muslim's Missionary of Procreation") (Latt 2020, p. 146). These are not available anymore, but the latter title indicates that tropes of Muslim sexuality and reproduction had entered Burmese nationalist discourses. In 1939, the notion of "Islamization" through mixed marriage also entered Parliamentary debate, when one MP showed his concern over a book in Urdu allegedly encouraging Indian Muslims to travel to Burma with the intent to convert Burmese women through marriage. ${ }^{16}$

In the context of rising Burmese nationalism-seeking independence both from British colonial rule and from India ${ }^{17}$-communal violence and questions of Buddhist women's inheritance rights, two laws were passed, which are of specific interest to us here, namely The Buddhist Women's Special Marriage and Succession Act (1939) and The Indo-Burma Immigration Agreement (1941). The Buddhist Women's Special Marriage and Succession Act $(1939)^{18}$ aimed at securing the inheritance rights of Burmese Buddhist women when marrying foreigners (as they then would be subject to Muslim, Christian or Hindu family laws). With regard to the Indo-Burma Immigration Agreement, it is of particular interest here that clause 14 prohibits male Indian immigrant workers to marry or cohabit with a Burmese woman, or his stay permit or visa will be canceled. In the racialized colonial economy, then, intimacy was not only to be regulated, but in fact prohibited for certain groups of migrant workers. As Chie Ikeya (2020, p. 770) points out: "The critics of intermarriage in colonial Burma singled out the Indo-Burmese kind as a particularly harmful form of intimate relations that reinforced political and economic colonization with cultural and biological imperialism". Her concept of "biological imperialism" is particularly useful as it captures the concern for demographic changes in the context of European colonialism in Asia, and while not a term emic to nationalist discourse, it very much resembles contemporary concerns in Myanmar.

As we shall see, there are strong similarities between the 1930s and the 2010s: transnational capitalist economy, a rise in nationalism and xenophobia and calls for antimiscegenation laws. The aim of the legal initiatives made both in the 1930s and in 2014/2015 were to protect Buddhist women and the in-group (amyo) versus perceived threats from defined out-groups (kala, Indians and/or Muslims). There are however, also some important differences to be noted. First, in the 1930s, The Buddhist Women's Special Marriage and Succession Act (1939) and The Indo-Burma Immigration Agreement (1941) were intrinsically linked to anti-colonial nationalist resistance against migration workers perceived to be part of the suppressive colonial order. In nationalist discourse they were perceived as an enemy from the outside with only temporary presence in Burma, who either should be expelled, or as suggested in The Indo-Burma Immigration Agreement, be legally prevented from having intimate relations with local women. Anti-Indian sentiments were continued under the military, but "Indophobia" eventually took a clearer anti-Muslim turn (Egreteau 2011). Also, there is evidence for anti-Muslim sentiments in the Buddhist monastic order (the Sangha) in the 1990s and 2000s. In spite of this, it is to be remembered that military rule ${ }^{19}$ in Burma/Myanmar, particularly under the rule of General Ne Win, did not emphasize religious difference and the years of direct military rule (1962-2011) witnessed relatively few instances of Buddhist-Muslim communal violence. ${ }^{20}$ The aforementioned colonial slogan of "A lumyo does not face extinction by being swallowed into earth, but from being swallowed up by another lumyo" became the motto of the Ministry of Immigration, but 
this slogan did not single out Islam or Muslims specifically. Rather, it was indicative of the general xenophobic nationalism produced by the military.

\section{The Rise of Buddhist Islamophobia}

"There's a perception that Muslim power, global Muslim power, is very great" Aung San Suu Kyui (BBC News 2013).

By the 2010s, the political contexts for anti-Muslim sentiments and anti-miscegenation laws had radically changed compared to previous periods of colonial rule and military dictatorship. The country had been independent for nearly 70 years, but suffered under military dictatorship, failed nation-building, civil wars and poverty. In 2003, the military began to address the poor economy and heavy dependency on China by opening up for political reforms, foreign investments and international tourism, as a part of a topdown "democratization" effort. With political liberalization in 2011, new public spaces for Buddhist protectionism and Buddhist legal activism opened up. The most dominant of these anti-Muslim Buddhist associations were "969"21 (established in 2012) and "MaBaTha" 22 (established in 2013). The 969, which was a loosely organized network of young activist monks, was highly visible in 2012 and 2013, producing anti-Muslim content in traditional media (printed press and sermons), but increasingly also in social media. The 969 monks became controversial for their strong anti-Muslim stance, the most famous being U Wirathu - the 969 spokesperson-who turned into an international media figure after being on a Time Magazine cover, titled "The Buddhist)" (Time Magazine, Europe, Middle East and Africa edition, 1 July 2013, 182:1). He was jailed in 2003 by the military for instigating anti-Muslim violence, but was released in 2012, together with political prisoners, as part of former President Thein Sein's political reforms. ${ }^{23}$ The 969 is the forerunner to MaBaTha, which by 2014 was eclipsed by MaBaTha. The latter changed its name to the Buddha Dhamma Parahita Foundation in 2017, but is still widely referred to by its old name, MaBaTha. In contrast to the $969, \mathrm{MaBaTh}$ is highly organized with a 52 member steering committee, national conventions and branches and sub-chapters all over Myanmar. Prominent MaBaTha monks are Organization chair U Tilawka Bhivamsa (also known as Insein Ywama Sayadaw), Sithagu Sayadaw and U Wirathu. Additionally, it is important to note that MaBaTha also includes lay women and men, making it a strong monastic-lay alliance across the country, including in the seven so-called "ethnic states" such as Shan and Karen. Under NLD rule (2016-2021) the organization witnessed restrictions and limited political support, but several of its leading monks have been seen as supportive of the military coup (Frydenlund et al. 2021). ${ }^{24}$

The context for the establishment of both the 969 and MaBaTha was the severe communal violence in the Rakhine state in 2011 and 2012. According to minutes from MaBaTha inaugural meeting in 2013, its mission is threefold: (a) to raise public awareness about the need for racial protection and the dangers of religious conflicts, (b) to establish peaceful co-existence among different religions in Myanmar through "unity and maintenance of discipline", and (c) to safeguard "race and religion within a legal framework" (see MaBaTha Minutes 2013). Amyo ("race") is the Burmese word used by MaBaTha, but as noted previously, amyo is polysemantic: it slides between signifying the Bamar "race" and the list of 135 groups codified by the state, thus including Buddhist ethnic minorities such as the Shan, Karen or Rakhine.

Common tropes and concerns in Buddhist protectionist ideology include notions of the intrusion by the non-Buddhist "Other", the need to protect Buddhism, and the justification of monastic involvement in social action. The great fear is that Islam will take over Buddhist majority states. This resembles right-wing conspiracy theories in Europe such as the Great Replacement. The term "The Great Replacement" is not used in discussions about Buddhist Islamophobia, but similar notions are found in the so-called "Green Belt theory", which sees as pattern of Islamization from Saudi Arabia to the Philippines. This "belt" is only interrupted by Buddhist Myanmar, and Myanmar is therefore seen as a "frontier state", resisting Islamization from Bangladesh in particular. 
Several observers have noted that rumors about Muslim men raping Buddhist women have been circulated on Facebook prior to instances of anti-Muslim violence. This was also the case when anti-Muslim violence broke out in Mandalay in July 2014; the night before the violence rumors about rape of a Buddhist girl by a Muslim man went viral on social media, including on a Facebook account in the name of U Wirathu. ${ }^{25}$ During the massive military campaign against the Rohingyas beginning on 25 August 2017-forcing nearly 700,000 Rohingyas to flee to Bangladesh-leading MaBaTha monks did not condemn the violence against civilians. Rather, leading monks such as Sithagu Sayadaw gave their support to the military efforts. In a sermon given on 30 October 2017 to Burmese soldiers-amidst the atrocities in Rakhine-Sithagu Sayadaw made reference to the Lankan $5^{\text {th }}$ century chronicle the Mahavamsa and to a specific passage where the killings of non-Buddhists are justified (Sithagu Sayadaw, Youtube, 30 October 2017).

Comparing colonial era "Indophobia" with the massive Islamophobia in the contemporary era, Nyi Nyi Kyaw (2016, p. 191, italics mine) makes an important observation by pointing out that "Islamophobia in present-day Myanmar does not target only Indian Muslims but all Muslim groups". Building on this observation, I would like to emphasize that ethnic difference among the various Muslim minority communities-and hence their different histories of migration and belonging in Burma/Myanmar-is erased and conflated into a one-dimensional religious identity, which is then construed as a threat to a Buddhist collective identity. Such erasure of ethnicity and/or geographical identities combined with the religionization of persons of Muslim background, is similar to processes in Europe (Yilmaz 2016). This follows a global logic or "template" along Huntingtonian lines of "Clash of Civilizations" and essentialist readings of cultural difference (and the downplay of class, ideology and ethnicity).

\subsection{Tropes of "Love Jihad"}

"Once you get married with Muslim guy, you'll definitely lose all your freedom, you can't even get a chance to offer flowers to the Buddha, far from going to monastery and worshipping to Buddha." (Ma War War Myint, Woman interviewed in "Human Rights Violations by Human Rights Activist", 2012, p. 17). ${ }^{26}$

At the heart of Buddhist Islamophobia are questions of "Islamization" through reproduction and sexuality. As previously noted, the term "Love Jihad" is not widely used in Burmese anti-Muslim discourse, although $U$ Wirathu has occasionally referred to the term "sexual jihad" (referring to the English term). ${ }^{27}$ My inquiries into this in 2020 and 2021 indicate that the term is known, but hardly in use. However, as this article suggests, a close content analysis of Buddhist Islamophobia in Myanmar during the years of semi-civilian rule and liberalization (2011-2021) shows a similar concern for alleged aggressive male Muslim sexuality and violent oppression of women, thus very much fitting into "love jihad" as an analytical category as proposed by Frydenlund and Leidig (Forthcoming). At the core are notions of the alleged sexual threat posed by Muslim men to non-Muslim women and that interreligious marriage is part of an intentional strategy of "Islamizing" non-Muslim cultures, in this case, Buddhist Myanmar. The 1939/1954 marriage laws show that concern for Buddhist women in interreligious marriages is not new. However, the discursive strategies to substantiate legal claims have shifted to include not only custody and inheritance, but also global discourses on religious freedom and women's rights. The following analysis is based on interview material with Buddhist monks and lay people active in the 969 /MaBaTha during its heights between 2012 and $2016^{28}$, as well as readings of legal texts to show how fears of male Muslim sexuality and miscegenation are crucial to Buddhist Islamophobia, seen as a form of "biological imperialism" to borrow Ikeya's concept, and which in form and content is almost identical to the Indian trope "Love Jihad".

In an interview with U Wirathu, he explains how he sees the process of Muslim allurement of Buddhist women into marriage: 
"There are lots of difficulties due to the Muslims, they cause problems. They rape Burmese Buddhist women in many towns and cities. They rape teenagers and children under age...The women are very vulnerable [in marriage]. The man pretends to be Buddhist, and then she is allured into Islam and she is forced to wear burqa. Some women are tortured if she continues the practices of her religion. If she is pregnant, she will be mistreated until miscarriage. In one case, a woman was even killed. If a woman of another religion marries a Muslim man she loses all her religious freedom and all her human rights...Then they are forced to commit sacrilege, for example to step on Buddha images. They force Buddhist women to sin...When we as monks give sermons we inform laypeople about these stories so that they can shy away from Muslim males." ${ }^{29}$

The four "race and religion" laws (discussed more in detail below) were designed to cover specific Muslim practices identified as a means to promote "Islamization". The first aspect relates to the (alleged) increase in the Muslim population and the fear of a future Islamic tyranny where Buddhists will become a persecuted minority, while the second aspect relates to allegations of forced conversion of Buddhist women by their Muslim husbands. Again, according to U Wirathu:

"There are so many stories of Buddhist women being beaten because of their Buddhist worship. We have documentation of that. One woman was beaten to death while her family held her. They even beat her vagina. In order to give Buddhist women freedom of worship, this law has to be passed. The point is that in Muslim families, unless you keep to the Islamic practice, you are considered a whore."

To MaBaTha, this conversion requirement is in itself a grave violation of the right to religious freedom. Moreover, they argue that Buddhist women marry Muslim males for economic reasons and thus that conversion is not based on "free will" but out of poverty and economic "allurement", echoing colonial era notions of economic competition, in spite the fact that many Muslim communities in Myanmar would be economically marginalized. Furthermore, MaBaTha's notion of "free will", rests on an understanding of religion as belief, and moreover, that this religious belief is autonomous vis à vis other kinds of rationale for action. Buddhist doctrinal notions of free will and conversion (to Buddhism) emphasise intellectual reasoning and individual choice. On a comparative note, this differs slightly from Hindutva "moral policing" of women according to notions of the ideal Hindu social order (e.g., Tyagi and Sen 2020), as the Buddhist anti-love jihad campaigns put emphasis on notions of individuality and a perceived urgency in securing the religious freedom of Buddhist women. Thus, while both Hindutva and Buddhist protectionist anti-love jihad activism share common notions of an anti-Muslim biopolitics, the reproduction of the nation through the female body and limitations on women's rights, there are important variations.

In addition to focusing on religious freedom issues for Buddhists, MaBaTha also showed concern for violence against women. Crucial to the narrative of Buddhist-Muslim marriage is Muslim male aggression and, in 2012, the 969 organised a series of public events to document such cases, through presentation of "real life stories". In such events, the identified Buddhist victim is interviewed by a Buddhist monk in front of a Buddhist audience. One such event was written down and published in the form of a booklet ${ }^{30}$ that was distributed by U Wirathu and his supporters during 2013 and 2014. In this text, we are introduced to a story called "The Victim's Voice who Just Escaped from Tigers", which is about a Burmese Buddhist woman called Ma War War Myint who has left her Muslim husband. Her story-a testimony of severe domestic violence-is framed within a Buddhist-Muslim dichotomy and conceptualised as a case of violations of religious freedom and of women's rights. The text is structured as a dialogue between Ma War War Myint and the Buddhist monk Ashin Kicsanobarsa. ${ }^{31}$ The text begins by explaining how the Muslim man had paid courteous attention to her in the local Pagoda grounds, 
even offering lights to the Buddha statues there. She accepted his marriage proposal after three months as she thought him to be Buddhist. Five months into their marriage, her husband told her to "not go to Buddhist temples and monasteries" (p. 4) and that she was not allowed to keep Buddhist books at home. "Then, only", Ma War War Myint continues, "he explained to me that he is a Muslim and forced me to convert to Muslim [Islam] as well" (p. 4). Then, a Muslim wedding ceremony was arranged in the mosque, forcing her to accept the nikah ceremony. She was then informed that she had become a Muslim. As a devout Buddhist at heart, the text goes on to explain, she continued to go to the monastery, but when her husband found out, he began to severely punish and torture her (pp. 5-6). The torture also resulted in miscarriage of their first child when seven months pregnant. The second son was given a Muslim name by the father, but at the hospital the mother had given him a Burmese Buddhist name. The wife explains:

"I hate not only Ko Kyaw Win (the husband) but also all the Muslim people. They are all just gazing whenever he tortures me. And nobody asks him to stop for me. [ ... ] In our Buddhist religion, far from being calm, we help others whoever [is] getting in trouble. They [the Muslims] just ignore because I am not their Muslim race. That's why I hate all Muslim people young or old" (p. 26).

In the text, we see that "Muslim" is explicitly constructed as a racial category. In several places it is stated that the husband is both of the Islamic religion and he is Muslim by "race". Also, the text shifts in denoting the husband as "Muslim" to the pejorative "kalar" (p. 10). Four tropes run through the text: (1) Muslims as violent against women; (2) the need to secure the religious freedom of Buddhist women; (3) Muslim male as hyper sexualized given that Ma War War Myint was the Muslim husband's third wife (the first being a Muslim, the second a Shan Buddhist); and (4) Islam as opposed to women's rights. The reason why Muslim men want to marry Myanmar "girls", according to Ma War War Myint, is "just to increase the Muslim population" (p. 22).

This text resembles the trope of "saving brown women", which over time has served as justification for British colonial rule (Burton 1994), or neo-colonial interventions such as "Operation Enduring Freedom" in Afghanistan (Abu-Lughod 2013). However, in the 969 "rescuing text", the point is not the rescue of Muslim women, but of Burmese Buddhist women from Muslim men, and thus of Buddhism itself (from Islam). Furthermore, in the text, a binary opposition is constructed: "Islam-violence-unfree" versus "Buddhism-nonviolence-freedom". Buddhism represents individual freedom and women's rights, Islam the opposite. As discussed above, the "freedom" discourse is where Buddhist anti-love jihad activism differs from its Hindutva sibling.

Buddhist women across Myanmar showed their support to both 969/MaBaTha and the four race and religion laws. The reason for this was a widespread belief that the laws would protect again sexual violence. Myanmar is among the few countries in Asia without a law against domestic violence and many Buddhist women thought the laws would finally offer legal protection against violence (Walton et al. 2015). Additionally, monks I interviewed in 2014 and 2015 sincerely believed that the laws would strengthen women's rights and protect them against domestic violence. However, the legal texts do not mention anything about sexual violence against women, and the whole logic behind the claim that the laws would protect against sexual violence rests on the notion that the danger of sexual violence in Burmese society comes from Muslim males. For example, Muslim men as rapists was a theme high on the agenda during the communal violence between Rakhine Buddhists and Rohingya Muslims in the Rakhine state (bordering Bangladesh) in 2011 and 2012. In fact, the massive anti-Muslim violence in 2012 was set off by the rape and murder of Ma Thida Htwe, a young Rakhine Buddhist girl, by three Rohingya men. It resulted in massive retaliation, and Ma Thida Htwe became a symbol for the threats allegedly posed by illegal Muslim immigration from Bangladesh (which is how Burmese Buddhists generally characterize the Rohingyas). Pictures of Ma Thida Htwe's dead body went viral on social media in Myanmar in the following years, and pictures of her (together with other victims of "Islamic violence" figured on posters at U Wirathu's temple walls. 
Rescuing women from rape, sexual violence and domestic violence-but notably only in marriage with non-Buddhist men-was a central theme in Buddhist nationalism in the years following the opening up of Myanmar in 2011; so too was the theme of monogamy (and the criminalization of polygamy. Such concerns are tied to modern global discourses on women's rights, but only adopted partially and selectively.

Thus, while recognizing the importance of colonial legacies of anti-Indian/antiMuslim narratives, it must also be noted that political liberalization, electoral competition, and access to internet and social media produced fertile grounds for new forms of Buddhist protectionism and Islamophobia. In this context, the enemy of Buddhism and amyo today is no longer neighboring Indians (or Chinese) but Global Islam, which is increasingly coming closer. At the same time, local Muslims (the Rohingya in particular) make claims of belonging to the state. Seen as a "myth of subversion", Muslims in Myanmar are constructed as an enemy within, one that is conspiring with global forces to alter the Buddhist social order. As such, MaBaTha conspiracy theories fit into traditional conspiracy theory thinking in that they are radical "nativists" whose enemy is an evil, subversive power from the outside that has undermined true values and stolen away freedom and power from the ingroup.

\subsection{The 2015 "Race and Religion Laws"}

At the heart of 969 and MaBaTha activism—and subject to much public tension—were four laws that were passed by the President and the Parliament in 2015 in order "to protect race and religion". ${ }^{32}$ As previously noted, Burma passed laws in 1939/1954 that (as the first in Asia) gave specific protection to Buddhist women in mixed marriage, with particular reference to inheritance and property rights. The 2015 "race and religion" laws, however, expanded on the 1954 law, but also added three more laws, which were aimed at securing women's rights and religious freedom (of Buddhist women).

The "race and religion" laws were top priority to the 969 and MaBaTha, and early drafts were presented at MaBaTha's inaugural meeting on 26-27 June 2013. At this early stage only two draft bills were presented: one on mixed marriage, the other on conversion. Early drafts that circulated in social media and among civil society organizations in 20132014 prescribed that only Buddhist men could marry Buddhist women. It was also stated (in an unofficial English draft) that any non-Buddhist man who married a Burmese-Buddhist woman would be punished with a ten-year prison term, and all his possessions and property would be confiscated and given to the Burmese-Buddhist woman he married in contradiction of this law.

The laws seek to regulate marriages between Buddhist women and non-Buddhist men, to prevent forced conversions, to abolish polygamy and extra-marital affairs, and to promote birth control and family planning in certain regions of the country. The laws were passed in great part due to mobilization of the 969 and MaBaTha, and the formations of these associations are organizationally, ideologically and historically intertwined with the legislative process.

The final laws are generic in language. However, MaBaTha claimed to have designed the laws specifically to prevent various aspects of "islamization" (Frydenlund 2017, 2018b). Leading activists confirmed in interviews ${ }^{33}$ that the aim of the Birth Control Law was to stop the escalating numbers of "illegal immigrants" (mostly referred to as "Bengalis", meaning Rohingyas), the aim of the Conversion Law was to prevent forced conversion of Buddhist women to Islam, the Marriage Law was to protect Buddhist women's right to religious freedom in marriages with Muslim males and to prevent sexual violence in marriage, while the Monogamy Law was aimed at reducing the size of Muslim families in Rakhine. MaBaTha's aim to stop "islamization" is largely framed in religious rights language, but also in a women's rights language, exemplifying how particular rightsthough generally thought of as expressing equality and universalism-can serve as a tool for identity politics and for marking of communal difference.

Previous research has shown how religious freedom issues and the "race and religion laws" were politicized during the 2015 elections (Frydenlund 2017) and how the global 
language of "religious freedom" were adapted by Buddhist activists in particular ways to protect the freedom of Buddhist women (Frydenlund 2018b). Likewise, feminist themes and women's rights were also top priority for MaBaTha and the law-makers in Parliament. Of particular concern was the notion of male Muslim polygamy. Up to 2015, Myanmar's Customary Law system — both Muslim and Buddhist Family Law-accepted polygamy. The Monogamy Bill sets out to protect women from being cowives, and to prevent crimes arising from polygamous acts of men (Preamble). Moreover, the law also contains a special "Prohibition on Extramarital Affairs" for both men and women, in which "extramarital affairs" are made illegal. "Extramarital affairs" are not defined in the law, but "matrimonial crime" (for example in the case of co-habitation with second wife) is sanctioned by loss of property rights (Art 14), as well as loss of inheritance rights for second wife. As we remember from the 969 booklet distributed by U Wirathu presenting the story of the Buddhist woman who escaped her violent Muslim husband, she was allured into marriage and conversion to Islam through romance and love. The "four race and religion" laws can be seen as an attempt to protect women such as Ma War War Myint from violence. Furthermore, global discourses on women's rights are discernible in the Population and Healthcare Law, not only because it mentions co-operation with UN agencies, but more than anything, because it introduces the concept of "birth-spacing", which in the law is defined as the practice of having at least a 36-month interval between one child birth and another for a married woman (Chapter $1, \mathrm{c}) \cdot{ }^{34}$ However, while the law is generic, and while birth-spacing might be recommendable for medical reasons, the specific contextthe widespread claim that Rohingya Muslims "breed like rabbits" and that the law is necessary to stop Muslim production of babies-implies that the law was seen as curbing the reproductive rights of Muslim Rohingya women, representing a specific form of antiMuslim biopolitics of the part of the Myanmar state.

As might be expected, laws to control conversion and mixed marriages, and to enforce family planning and the criminalization of extra-marital affairs, were met with fierce opposition from local and international human rights organizations for not being in accordance with international human rights standards. ${ }^{35}$ With regard to women's rights, activist groups and civil society organizations vigorously protested the laws as a violation of the right to privacy, arguing that "Religion, family planning and reproduction, and marriage are subjects integral to the private lives of people. The Government cannot and should not control these areas of people's lives through laws". ${ }^{36}$ Unlike the anti-conversion bill process in Sri Lanka, or the protests against "Love Jihad" legislation in India, in Myanmar religious minority groups did not vocally oppose the laws. Muslim communities were not in a position to protest the laws, given the recent anti-Muslim violence and widespread discrimination, although it should also be noted that many Muslims did not necessarily regard the laws as applicable to them.

Few cases have been held in Burmese courts, and under the NLD government (20162021) the laws were thought of as "dormant", with little influence on people's daily lives. Additionally, as Melissa Crouch (2016) has shown, with regard to the Monogamy Law, MaBaTha activists did not achieve their intended aim of criminalizing Muslim men taking Buddhist wives, co-wives or mistresses, as most court cases (up to 2020 at least) were initiated by Burmese Buddhist women who sued their cheating husbands. During fieldwork in Yangon in 2018 and 2019, this was confirmed by female Buddhist activists and lawyers, who saw the laws as an empowerment of women, giving women a legal tool against unfair treatment in marriage. ${ }^{37}$

However, again, it is not to be forgotten that the laws were passed in the context of massive anti-Muslim campaigns and that for interreligious relations and for religious minority communities — and Muslim minority communities in particular-the laws had severe consequences, if not in the courtroom then at the societal level. First, it showed to them that Buddhist protectionism could be effectively mobilized for Buddhist rights at the expense of minority protection. Second, there is an important shift in how social identities are managed: while the 1954 Act referred to mixed-marriage couples (regardless 
of the religious identity of the male) according to Buddhist Customary law (so-called Dhammathat legislation), the new law differentiates legal subjects on the basis of religion, thus accentuating religious difference. Third, it sent a clear signal that inter-religious marriages were not only undesirable, but a threat to the nation itself. Finding BuddhistMuslim couples in this period who were willing to partake in research on mixed marriages turned out to be almost impossible as people felt it to be too sensitive and politicized. Fourth, as also noted by Crouch (2016, p. 99) the law was used in contemporary debates to ensure that "Burmese Buddhist law trumps Islamic law".

\section{Global Tropes and New Forms of "Nationalism"}

While a comparison of "Love Jihad" campaigns and legislation in India and the 2015 "race and religion" laws in Myanmar indicate clear structural similarities of preventing "Islamization" through marriage by legal action, identifying a clear influence from India to Myanmar-or the other way around-seem difficult, and future archival research is needed to tease out possible transnational circulation of ideas related to miscegenation laws and/or anti-conversion legislation. ${ }^{38}$ One possible explanation for its limited circulation (beyond U Wirathu) might be that the "jihadification of everything" (as we see in India) is closely linked to a highly efficient digital echo-system of Hindutva politics and anti-Muslim propaganda under Narendra Modi (2014-) and that the primetime of 969 and MaBaTha predates the global digital Hindutva machinery we see today. However, Myanmar-India relations have been amicable over the last few decades, partly due to the wish of the generals in the 1990s and early 2000s to become more independent from China. This has meant, among other things, that Buddhist pilgrims go on pilgrimage, for example, to Bodh Gaya, that Burmese monks go to India for education, or that Indian monks stay at the state-run Buddhist monastic universities in Yangon and Mandalay. Furthermore, although more research is required to document Hindutva activities in Myanmar, we can identify some traces of RSS activity in Myanmar. Global Hindutva, as shown by Christophe Jaffrelot (2021), is not the result of long-term nationalism from diaspora groups back "home", but has been a planned centrifugal force, radiating from India to diaspora communities across the world. Hindu communities in Myanmar today are numerically small and always in a vulnerable situation due to their Indian ancestry ${ }^{39}$, but also more protected than Muslim communities (of all ethnic backgrounds) given their cultural closeness to Buddhists within an Indic religious cultural framework. One example of Hindutva activity in recent years was reported by the RSS in India regarding an event in Yangon in 2000. In the RSS records it reads:

The 50th anniversary of the Sanatan Dharma Swayamsevak Sangh (SDSS-The RSS counterpart in Burma) was held at the National Theatre on Mayoma Kyaung Street, Yagnon, recently. Secretary-2 of the State Peace and Development Council, Lt. Gen. Tin Oo attended the meeting. The programme was attended by ministers and senior military officers. Minister for Commerce, Brig. Gen. Pyi Sone; Minister for Social Welfare, Relief and Resettlement, Maj. Gen. Sein Htwa; Minister for Health, Maj. Gen. Ket Sein were among the prominent persons who attended the function. The Secretary-2 delivered speech at the function. ${ }^{40}$

Future study would need to investigate the scale and importance of such meeting places between the RSS and the Tatmadaw, and furthermore, how such meetings were presented (if at all) in the military propaganda machinery at the time. What we can state with clarity is that RRS India saw the importance of reporting on the event. Seventeen years later, a visit by Yogi Adityanath, BJP chief Minister of Uttar Pradesh-long-time yogi, Hindutva activist and anti-love jihad campaigner-to Myanmar was widely reported by Indian media. In Indian media, it was given utmost importance that Yogi Adityanath chose to make Myanmar his "maiden visit" abroad after his 2017 elections. His visit in August 2017 (just two weeks before the ethnic cleansing of the Rohingya began) was widely covered in India (but less in the Burmese press). He was invited by the Vivekananda Mission (linked to the BJP), but, importantly, also by Ven. Sithagu Sayadaw, one of the leading monks of MaBaTha, who has a wide international network in Asia, as well as in the USA. At 
Sithagu's previous Peace Conference, held in 2016 in Sagaing, Indian Buddhist monks and lay people participated, but Hindu nationalists or other individuals linked to BJP or RSS did not present papers. ${ }^{41}$ Two years later, Yogi Adityanath was invited as the Chief Guest at the conference, giving a long "spiritual speech" on the importance of the dharmic religion and the relevance of the Buddha's teachings today. He talked about the Buddhist Circuit plans in Uttar Pradesh and the importance of Buddhist pilgrimage in the region, thus tying Burmese Buddhist pilgrims closer to his visions of Hindu cultural heritage and sanatana dharma. On the role of co-operation, he pointed out that "Different organisations of the world have responsibility to establish mutual cooperation and coordination". He also spoke of the need to join the energies of the religious, the political and academic forces. This was seen by the organizers as a great support to their mission and work. ${ }^{42}$ Therefore, while Buddhist protectionism in Myanmar very much revolves around local concerns, it is also true that monks associated with MaBaTha, such as Sithagu Sayadaw or U Wirathu, have ties with Hindutva activists in India, as well as with Buddhist associations in Sri Lanka and Thailand.

When it comes to online Islamophobia, we know that Facebook and Twitter were crucial in spreading Islamophobic content in the years 2012-2016, and during the 2017 ethnic cleansing of the Rohingya (Serrato 2018). To give but one example of such digital content, we can look at a Facebook group called "The Buddhist Defence League Myanmar" modelled on the right-wing nationalist organization the English Defence League-where a picture of Ma Thida Htwe figures as the group's visual representation on Facebook. The aim of the group is to defend "Buddhist all over the world from jihadists" ${ }^{43}$ In addition to pictures of Ma Thida Htwe, the page contains pictures of dead children (unknown context and origin), with the headline: "Bangladesh: Fascist settlers using rape as a tool of Islamic Jihad", thus discursively construing rape in Myanmar as a result of Islamic violence and expansionism. This Facebook group, in spite of its few followers, is of interest because of its similarity to groups established in 2014-2016, in Sri Lanka, India, the UK and in Norway, using a "global template" of "Defence League" groups on Facebook, alluding to the right-wing and contra-jihadist extremist group the English Defence League.

Additionally, it is to be noted that U Wirathu in 2020 and 2021 has gained attraction in India, for example at the Youtube channel Lallantop. ${ }^{44}$ The program ${ }^{45}$ introduces U Wirathu, 969 and the conflict in Rakhine to a Hindi-speaking audience. After little more than a year, it has more than 19 million views, and as of September 2021 the comments section included more than 30,000 comments (mostly in Hindi), overwhelmingly showing support to U Wirathu. Echoing many others, one of these comments stated that "Wirathu rightly said that 'no matter how peaceful you are, you cannot sleep with a mad dog, these sayings apply to the whole world.'" Numerous other comments made the connection between Yogi Adityanath and U Wirathu, seeing them as true defenders of their nations against the perceived threats of Islam. Other comments concerned "the need for population control", or concerned Kashmir, effectively linking the Rohingya issue to other border states in India. The comments section must be understood in the context of several anti-Muslim Hindutva campaigns during the COVID-19 pandemic (including the "corona-jihad meme"), severe anti-Muslim violence in New Delhi in January 2020 and the Citizenship Amendment Act (from late 2019), seeing Muslim refugees as a major threat (Malji and Raza 2021). Hindutva politicians were particularly antipathetic to Rohingya refugees from Myanmar, and U Wirathu's anti-Muslim and anti-Rohingya rhetoric seemed to fit neatly into the online Hindutva sympathizers in the commentary section. Thousands of comments and "likes" expressed the idea that India also needed a "holy man like Wirathu", often followed by the clasped-hand emoji.

\section{A Buddhist Femonationalism?}

At the heart of femonationalism lie assumptions of the Muslim man and woman as the main representatives of the binary oppressor and victim (Farris 2017). This, as argued above, is a recurrent theme in 969 and MaBaTha discourse, which eventually resulted in 
the 2015 "race and religion laws" in Myanmar. However, as the material analyzed above suggests, Buddhist protectionists are not really concerned with rescuing Muslim women, although texts such as the booklet "Human Rights Violations" discussed above declared that Muslim women are oppressed. While the suggested policy of "birth-spacing" (as suggested in one of the four "race and religion" laws) borrows language and concepts from UN development programs for women, the context for this policy is not concerns for Rohingya female welfare, but notions of Rohingya hyper-reproduction, which it was claimed by hardline MaBaTha monks would eventually result in a Muslim takeover of Buddhist Myanmar.

Building on Gyatri Spivak's famous observation about British "civilizational" projects in British India about "White men claiming to be saving brown women from brown men", Farris notes how contemporary right-wing nationalism in Western Europe has been deeply concerned about saving the female victim "Other" from the male "Other" who is seen as a sexual threat, the West seen as a savior of those women from the male "Other". How does this work in the Buddhist context? The first thing to note is that Buddhist protectionist constructions of "love jihad" and the sexually threatening Muslim male is made in the context of intra-Asian intimacies. As discussed in this article, notions of ingroup, ethnicity, "race" (amyo) indeed follow colonial racialized logics, but such constructions operate outside of a white-brown binary. As we remember, the Burmese have been far more concerned with Indian and Chinese males than with "whites". Thus, understanding anti-Muslim nationalism in Asia needs to expand beyond theories of "whiteness". Such theories, as Ikeya points out (2017, p. 120), have "rendered some bodies and socialities more epistemologically relevant than others". In Burma/Myanmar the threatening male Other is-as it was in the 1920s and 1930s-other Asian males, Indians in particular. With time, Indianness was downplayed and Islam and Muslim males were presented as the great threat. In such discourses the notion of "race" and "ethnicity" are prevalent, but its signifiers are contextual and in flux, shifting between notions of Bamar biological "race" to include all 135 "national races" in Myanmar, to signify the Buddhist in-group (and by that racializing Buddhism). Therefore, if we expand the notion of femonationalism to move beyond white right-wing nationalism in Europe (and North America) to also include non-white right-wing nationalism, nativism and religious protectionism we can see that concerns for women's rights, sexual and domestic violence, and freedom of religion all play a crucial role in current Islamophobic formations in Asia as well. It is less a question of rescuing Muslim women (born Muslim) as it is about rescuing Buddhist women out of "forced" Muslim marriages and conversion, but the focus on feminist themes and human rights in nationalist/religious protectionist discourse is similar. As such, the construction of a "Global Muslim Other" as violent and against human rights has shaped a Buddhist protectionist identity that stands for women's rights, freedom of religion and all things "modern". Brubaker (2017, p. 21) observes that in European nationalist populism "less emphasis is placed on national difference (notably language and specifically national cultural particularities and traditions)" and that more emphasis is now given to "JudeoChristian civilization". Islamophobia in Myanmar is not there yet, but with increasing pan-ethnic Buddhist protectionism, increased contact with similar groups in Thailand and Myanmar, and Hindutva admiration for MaBaTha and monks such as U Wirathu, one might imagine a stronger Buddhist-Hindu alliance, promoted by authoritarian regimes in the region, against global Islam, but also against local Muslim minorities in Buddhist and Hindu majority states in Asia.

\section{Postscript: Notes on the Coup and the Future of Buddhist Islamophobia}

The military coup in Myanmar on 1 February 2021 ended semi-civilian rule (20112021), bringing the country once again under direct military rule, led by the State Administration Council (SAC). The coup was met with massive protests, which have radically transformed political as well as military dynamics. Within days, hundreds of thousands of people took to the streets demanding an end to military rule, the release of Aung San Suu 
$\mathrm{Kyi}$, the release of 400 members of parliament under house arrest, and the restoration of the elected government. At the same time, the Civil Disobedience Movement (CDM) was formed, which quickly spread across the public sector and included a wide range of civil society organizations and religious institutions. The massive protests were characterized by global internet culture, interreligious solidarity, and new visions for a plural and democratic Myanmar. The hallmarks of the anti-coup protest were broad involvement of youth (often referred to as Gen Z), interreligious solidarity, the liberal expression of multiple identities in public space, and the use of digital communication (Frydenlund et al. 2021, pp. 78-79). In addition to the unprecedented level of interreligious and cross-ethnic solidarity in public space, sexuality also played an important part in the protests. In Myanmar, sexual ridicule and playing with traditional notions of purity/impurity has for long been part of democratic resistance to military rule, as the military is marked by violent masculinity, heteronormativity and conservative gender roles, (Khin Mar Mar Kyi 2012). For example, hanging women's longyis (loin cloth) in public spaces for soldiers to pass under and thus become ritually impure, or sending dirty women's laundry to Myanmar embassies, have for long been a tactic to challenge the military from within a particularly Burmese cultural ethos (ibid.). Furthermore, by bringing digital "shit-posting" culture to the streets, posters frequently sexually ridiculed the generals in ways totally unprecedented in the Myanmar context. After a few weeks, the Tatmadaw began its brutal crackdown. Simultaneously, the military began its legitimation strategies, framing the coup within a Buddhist symbolic framework (Frydenlund et al. 2021, pp. 84-85). In a statement from the Young Men Buddhist Association (YMBA) where, among other things, General Min Aung Hlaing is declared a bodhisattva, the military propaganda machine declared that killing civilian protesters is legitimate as a necessary means to protect the buddhasasana. Interestingly, in the same document, the Tatmadaw (through the YMBA), raises its concern over mixed marriages, saying that as you comrades know, during this decade of so-called democratic transition, the buddhasasana waned because they (the NLD government) favored foreigners who took the locals' positions and married Burmese Buddhist women. Now, fortunately, the vanguard of the buddhasasana, the embryo buddha (Senior General MAH) came to power and the war shall be won and the buddhasasana shall flourish again. ${ }^{46}$

Thus, the now-declared Buddhist military state (led by a general who is presented as a buddha-to-be) will protect against the alleged decline of Buddhism, foreign influence, and cross-cultural marriage between Burmese Buddhist women and "foreign men". With this, the military state-justified with reference to a peculiar military ideology based upon its own version of Myanmar nationalism and Buddhist protectionism - will present itself not only as the protector of Burmese Buddhist women, but through the female body, as protectors of the buddhasasana.

Funding: This research was funded by the Research Council of Norway, grant number 287230 .

Institutional Review Board Statement: Not applicable.

Informed Consent Statement: Not applicable.

Data Availability Statement: Not applicable.

Acknowledgments: The author wishes to thank the INTERSECT research team for input and support, and to two anonymous reviewers for their insightful feedback. All shortcomings are mine.

Conflicts of Interest: The author declares no conflict of interest.

\section{Notes}

For more on the construction of "national races" (thain yin-tha) and the 135 state codified "racial" groups in Myanmar, see Nick Cheesman (2017).

2 Ethnicity in pre-modern Burma also seems to be fluid and contextual. This can partly be explained with marriage being a mechanism for acculturation and for the cultivation of allegiance (Ikeya 2020, p. 760). 
3 In some of my interview material with MaBaTha monks and nuns in 2014 and 2015 regarding the four race and religion laws, amyo explicitly referred to all 135 groups, not only the Buddhist ones. This is more in line with Myanmar nationalism as produced by the military, which seeks to include all groups under their notion of the "nation", and thus curb ethnic separatism.

$4 \quad$ This builds on earlier work (Frydenlund 2017; Frydenlund 2018b).

5 For more on "Eurabia" and the rise of Islamophobia in European white nationalism, see Bangstad (2014).

6 For a recent study of how law is used to curb Muslim communities in Myanmar, see Nyi Nyi Kyaw (2021).

7 This concern over numbers, Farzana Haniffa (2020) rightly points out, is connected to Sinhala notions of democracy as majority rule, or what has been defined as "ethnocracy".

8 The question of "Love Jihad" was, however, raised with regard to one of the women who participated in the 2019 Easter attacks, as she was a Tamil Hindu convert to Islam. Indian press reported on this case as yet another case of "Love Jihad". Conversion legislation has certainly been high on the agenda for Buddhist activists in the early 2000s, but then anxieties evolved around Christian Evangelical "unethical conversions". Bills to regulate conversion were never adopted in Sri Lanka.

9 The Pali word sasana (in Burmese: thathana) refers to the teachings, practices and institutions established by a particular buddha. It is understood to exist for a particular period of time before it disappears altogether. By comparison, buddhadharma is understood to be eternal and independent of time.

10 Colonial racial hierarchies, including the ambiguous position of Indian colonial elites, are brilliantly captured by Georg Orwell in his famous Burmese Days (1934).

11 This line of argument is supported by the fact that generally, local Buddhist legal texts (prior to British colonialism) did not proscribe against interethnic, interracial, or interfaith marriage. For an excellent overview of the status of mixed marriages in pre-modern Burma, see Ikeya (2020, pp. 758-62).

12 One of the great contributions of Phyo Win Latt's work is to show that there was no single understanding of amyo during the colonial era, and different stakeholders utilized the concept for different objectives and in different ways.

13 The British administration employed a similar term, "Indo-Burman", to refer namely to the Burmese vernacular term zerbadee, the descendant of a Muslim father and a Burmese Buddhist mother. Neither the term "Indo-Burman" nor zerbadee was used to include the offspring of non-Muslim Indian men and Burmese women, for which the census did not provide a separate category. Chinese Buddhist law was considered too different to be applicable (Ikeya 2013).

15 Already in 1906, news articles appeared on the risk for Burmese Buddhist women of losing their inheritance rights when marrying Hindus (Latt 2020, p. 153).

16 For more detail, please see Pyo Win Latt (2020, p. 155).

17 Burma was formally a province of British India from 1862 to 1937. In the 1930s, there was much debate about Burma's future relations to India.

18 Not put into proper legal practice until after Independence and then with minor revisions as the 1954 Law.

19 Military rule in Burma/Myanmar (1962-2011, 2021-) was initially informed by socialist ideology, but changed later to a military law-and-order ideology. With the 2008 Constitution, the military is informed by a mix of militarism, nationalism, Buddhism and capitalism.

20 In 1967, severe anti-Chinese riots took place, but in the period between 1938 and 2012, only minor instances of Buddhist-Muslim communal violence are recorded (in 1988, 1997 and 2001).

21 The name refers to the nine qualities of the Buddha, the six of the Dhamma, and the nine of the Sangha, which together constitute the Three Jewels of Buddhism. Additionally, the 969 stands as a discursive anti-thesis to "786", which is the numerical representation oft the first verse of the Qur'an, and is commonly at display in Muslim shops.

MaBaTha is an acronym for Ah-myo Batha Thathana Saun Shaung Ye a-Pwe, or the "Organization for the Protection of Race and Religion".

23 U Wirathu turned himself in on December 2020 (after being on the run since 2019 after allegations of defamation of Aung San Suu Kyi), but was released in September 2021 by the military coup government. Other leading MaBatha monks and laypeople have been strongly opposed to the 1 February coup.

There were several accounts under this name and who was behind this account remains unclear. However, that the real $U$ Wirathu was indeed very active on Facebook in this period was confirmed in personal interviews with him in the same period. Information booklet about the alleged dangers of Muslim men to Buddhist women called "Human Rights Violations by Human Rights Activist", distributed in the New Masoyein Monastery in 2013 and 2014. On file with author.

27 For example, in the Barbet Schroeder film The Venerable $V$.

28 In the aftermath of the 2017 anti-Rohingya violence, Facebook banned several accounts and put stricter monitoring in place. This, together with the fact that the NLD government gave less space to MaBaTha, implied a dip in Buddhist protectionist activism.

29 Interview, translated from Burmese to English, Mandalay, 5 June 2015.

30 "Human Rights Violations by Human Rights Activist" (2012). 
Control of Population and Health Care Law No 28/2015; the Religious Conversion Law (Conversion Law) No 48/2015; the Myanmar Buddhist Women Special Marriage Law No 50/2015 (Marriage Law); the Monogamy Law No 54/2015.

33 Interviews with U Wirathu and U Maung Chun, 2015.

34 The World Health Organization, for example, recommends 24 months between pregnancies.

35 Joint statement from 180 organizations submitted to Parliament called "Comments from Women's Organisations/Net- works and Civil Society on the 4 Bills to Protect Nation" (English version) on file with author.

Ibid.

Interviews with legal aid groups for women, Yangon, 2018 and 2019.

India has a history of anti-conversion legislation, but in the context of rising Hindu nationalism in the 1990s, four more states adopted similar legislation: see CS Adcock (2014). Anti-conversion legislation has for long been in place in several Indian states, and also been discussed (but dismissed) in Sri Lanka. As far as I know, the Myanmar "race and religion laws" were the first in the region to link conversion and mixed marriage in the legal domain.

39 Many Hindus of Indian background in Myanmar do not have full citizenship rights, according to the 1982 law and state codification of "national races".

40 Quoted in an article at HindutvaWatch, https://hindutvawatch.org/india-its-neighborhoods-rss-building-a-deadly-allianceagainst-muslims-and-christians/ (accessed on 25 August 2021).

$41 \quad$ Fieldwork notes, Sagaing, 2016.

42 https://www.youtube.com/watch?v=d22RkJ7Ddzk (accessed on 25 August 2021).

43 Accessed 9 March 2020.

44 As of August 2021 the Youtube channel had more than 19 million subscribers.

45 https://www.youtube.com/watch?v=ZsEkW9scPJc (accessed on 25 August 2021).

46 YMBA statement May 2021.

\section{References}

\section{Primary Sources}

"Human Rights Violations by Human Rights Activist". 2012.

MaBaTha Minutes. 2013. Included in the Draft Bill Called "Myanmar Women's Special Marriage Law (Bill)." Translated from the Burmese. On file with author.

Control of Population and Health Care Law No 28/2015.

The Religious Conversion Law (Conversion Law) No 48/2015.

The Myanmar Buddhist Women Special Marriage Law No 50/2015 (Marriage Law).

The Monogamy Law No 54/2015.

\section{Secondary Sources}

Abu-Lughod, Lila. 2013. Do Muslim Women Need Saving? Cambridge: Harvard University Press.

Adcock, Cassie S. 2014. The Limits of Tolerance: Indian Secularism and the Politics of Religious Freedom. Oxford: Oxford University Press.

Appadurai, Arjun. 2006. Fear of Small Numbers: An Essay on the Geography of Anger. Durham: Duke University Press.

Bangstad, Sindre. 2014. Anders Breivik and the Rise of Islamophobia. London: Zed Books.

BBC News. 2013. Suu Kyi blames Burma violence on 'climate of fear'. BBC News, October 24.

Braun, Eric. 2013. The Birth of Insight: Meditation, Modern Buddhism, and the Burmese Monk Ledi Sayadaw. Chicago: University of Chicago Press.

Brubaker, Rogers. 2017. Between Nationalism and Civilizationism: The European Populist Moment in Comparative Perspective. Ethnic and Racial Studies 40: 1191-226. [CrossRef]

Burton, Antoinette M. 1994. Burdens of History. In British Feminists, Indian Women, and Imperial Culture, 1865-1915. London: The University of North Carolina Press.

Campbell, Stephen, and Elliott Prasse-Freeman. 2021. Revisiting the Wages of Burman-Ness: Contradictions of Privilege in Myanmar. Journal of Contemporary Asia 1-25. [CrossRef]

Cheesman, N. 2017. How in Myanmar 'National Races' Came to Surpass Citizenship and Exclude Rohingya. Journal of Contemporary Asia 47: 461-83. [CrossRef]

Crouch, Melissa. 2016. Promiscuity, Polygyny, and the Power of Revenge: The Past and Future of Burmese Buddhist Law in Myanmar. Asian Journal of Law and Society 3: 85-104. [CrossRef]

Das, Veena. 1995. Critical Events: An Anthropological Perspective on Contemporary India. Delhi: Oxford University Press.

Egreteau, Renaud. 2011. Burmese Indians in Contemporary Burma: Heritage, Influence, and Perceptions since 1988. Asian Ethnicity 12: 33-54. [CrossRef]

Farris, R. Sara. 2017. In the Name of Women's Rights: The Rise of Femonationalism. Durham: Duke University Press. 
Foxeus, Niklas. 2019. The Buddha was a devoted nationalist: Buddhist nationalism, ressentiment, and defending Buddhism in Myanmar. Religion 661-690. [CrossRef]

Frøystad, K. 2021. Sound Biting Conspiracy: From India with “Love Jihad”. Religions 12: 1064. [CrossRef]

Frydenlund, Iselin. 2017. Religious Liberty for Whom? The Buddhist Politics of Religious Freedom during Myanmar's Transition to Democracy. Nordic Journal of Human Rights 35: 55-73. [CrossRef]

Frydenlund, Iselin. 2018a. Buddhist Islamophobia: Actors, Tropes, Contexts. In The Brill Handbook of Religion and Conspiracies. Edited by Asbjørn Dyrendal, Egil Asprem and David G. Robertson. Leiden: Brill, pp. 279-302.

Frydenlund, Iselin. 2018b. The Birth of Buddhist Politics of Religious Freedom in Myanmar. Journal of Religious and Political Practice 4: 107-21. [CrossRef]

Frydenlund, Iselin, and Michael Jerryson. 2020. Introduction. In Buddhist-Muslim Relations in a Theravada World. Edited by Iselin Frydenlund and Michael Jerryson. Singapore: Palgrave Macmillan, pp. 1-21.

Frydenlund, Iselin, and Eviane Leidig. Forthcoming. Introduction: "Love Jihad": Sexuality, Reproduction and the Construction of the Predatory Muslim Male. Religions.

Frydenlund, Iselin, Susan Hayward, Phyo Wai, and Za Pum Maung. 2021. Religious Responses to the Myanmar Military Coup. Review of Faith and International Affairs 19: 77-88. [CrossRef]

Gupta, Charu. 2016. Allegories of "Love Jihad" and Ghar Vāpasī: Interlocking the Socio-Religious with the Political. Archiv OrientáLní 84: 291-313.

Haniffa, Farzana. 2020. Sri Lanka's Anti-Muslim Movement and Muslim Responses: How Were They Gendered? In Buddhist-Muslim Relations in a Theravada World. Edited by Iselin Frydenlund and Michael Jerryson. Singapore: Palgrave Macmillan, pp. $139-68$.

Ikeya, Chie. 2013. Colonial Intimacies in Comparative Perspective: Intermarriage, Law, and Cultural Difference in British Burma. Special issue. Journal of Colonialism and Colonial History 14. [CrossRef]

Ikeya, Chie. 2017. Transcultural Intimacies in British Burma and the Straits Settlements: A History of Belonging, Difference, and Empire. In Belonging Across the Bay of Bengal: Religious Rites, Colonial Migrations, National Rights. Edited by Michael Laffan. London: Bloomsbury, pp. 117-38.

Ikeya, Chie. 2020. Belonging Across Religion, Race, and Nation in Burma-Myanmar. In The Palgrave International Handbook of Mixed Racial and Ethnic Classification. Edited by Zarine L. Rocha and Peter J. Aspinall. London: Palgrave Macmillan, pp. 757-78.

Jaffrelot, Christophe. 2021. Global Hindutva. Paper presented at the Dismantling Global Hindutva Conference, September 10-12. Available online: https: / / dismantlinghindutva.com (accessed on 10. September 2021).

Jerryson, Michael, and Iselin Frydenlund. 2020. Buddhists, Muslims and the Construction of Difference. In Buddhist-Muslim Relations in a Theravada World. Edited by Iselin Frydenlund and Michael Jerryson. Singapore: Palgrave Macmillan, pp. $263-297$.

Khin Mar Mar Kyi, Ma. 2012. In Pursuit of Power. Politic, Patriarchy, Poverty and Gender Relations in New Order Myanmar/Burma. Ph.D. dissertation, National University of Australia, Canberra, Australia.

Kyaw, Nyi Nyi. 2016. Islamophobia in Buddhist Myanmar: The 969 Movement and Anti-Muslim Violence. In Islam and the State in Myanmar: Muslim-Buddhist Relations and the Politics of Belonging. Edited by Melissa Crouch. Oxford: Oxford University Press, pp. 183-210.

Kyaw, Nyi Nyi. 2019. Adulteration of Pure Native Blood by Aliens? Mixed Race Kapya in Colonial and Post- Colonial Myanmar. Social Identities 25: 345-59. [CrossRef]

Kyaw, Nyi Nyi. 2021. The Excuse of (Il)legality in Discriminating and Persecuting Religious Minorities: Anti-Mosque Legal Violence in Myanmar. Asian Journal of Law and Society 8: 108-31. [CrossRef]

Latt, Phyo Win. 2020. Protecting Amyo: The Rise of Xenophobic Nationalism in Colonial Burma. 1906-1941. Ph.D. dissertation, National University of Singapore, Singapore. Unpublished.

Malji, Andrea, and Syed Tahseen Raza. 2021. The Securitization of Love Jihad. Religions 12: 1074. [CrossRef]

Nielsen, K.B., and A.G. Nilsen. 2021. Love Jihad and the Governance of Gender and Intimacy in Hindu Nationalist Statecraft. Religions 12: 1068. [CrossRef]

Robertson, David G., Egil Asprem, and Asbjørn Dyrendal. 2018. Introducing the Field: Conspiracy Theory in, about, and as Religion. In The Brill Handbook of Religion and Conspiracies. Edited by Asbjørn Dyrendal, Egil Asprem and David G. Robertson. Leiden: Brill, pp. 1-18.

Sarkar, Tanika. 2018. Special guest contribution: Is love without borders possible? The Feminist Review Collective 119: 7-19. [CrossRef]

Schober, Juliane. 2011. Modern Buddhist Conjunctures in Myanmar. Cultural Narratives, Colonial Legacies, and Civil Society. Honululu: University of Hawai'i Press.

Schonthal, Benjamin, and Matt J. Walton. 2016. The (New) Buddhist Nationalisms? Symmetries and Specificities in Sri Lanka and Myanmar. Contemporary Buddhism 17: 81-115. [CrossRef]

Serrato, Ray. 2018. Twitter's Myanmar Hate Machine. Ray M. Serrato (blog). Available online: https://rayms.github.io/2018-05-09 -twitter-s-myanmar-hate-machine/ (accessed on 25 August 2021).

Silva, Kalinga Tudor. 2016. Gossip, Rumor and Propaganda in Anti-Muslim Campaigns of the Bodu Bala Sena. In Buddhist Extremists and Muslim Minorities. Edited by John Clifford Holt. New York: Oxford University Press.

Stoler, Ann L. 2002. Carnal Knowledge and Imperial Power: Race and the Intimate in Colonial Rule. Berkeley: University of California Press.

Strohl, David James. 2018. Love jihad in India's moral imaginaries: Religion, kinship, and citizenship in late liberalism. Contemporary South Asia 27: 27-39. [CrossRef] 
Turner, Alicia. 2014. Saving Buddhism: The Impermanence of Religion in Colonial Burma. Honululu: University of Hawai'i Press.

Tyagi, Aastha, and Atreyee Sen. 2020. Love-Jihad (Muslim Sexual Seduction) and ched-chad (sexual harassment): Hindu nationalist discourses and the Ideal/deviant urban citizen in India. Gender, Place \& Culture 27: 104-25.

Walton, Matthew J. 2013. The "Wages of Burman-ness:" Ethnicity and Burman Privilege in Contemporary Myanmar. Journal of Contemporary Asia 43: 1-27. [CrossRef]

Walton, Matthew J. 2017. Buddhism, Politics and Political Thought in Myanmar. Cambridge, UK: Cambridge University Press.

Walton, Matthew J., Melyn McKay, and Daw Khin Mar Mar Kyi. 2015. Women and Myanmar's "Religious Protection Laws". Review of Faith and International Affairs 13: 36-49. [CrossRef]

Yilmaz, Ferruh. 2016. How the Workers Became Muslims. Immigration, Culture, and Hegemonic Trans formations in Europe. Ann Arbor: University of Michigan Press.

Yuval-Davis, Nira. 1997. Gender and Nation. London: Sage Publications. 